\title{
Ketamine - a unique adjuvant drug in pain treatment
}

\begin{abstract}
Ketamine is an anaesthetic with unique properties. Synthesised for the first time in the early 1960s, it causes dissociative anaesthesia, sedation, amnesia, and analgesia. Due to hallucinogenic effects, the use of the drug was significantly reduced in the 1980s. At present, ketamine is used to treat acute and chronic pain, especially pain resistant to other pain management methods. Ketamine can be effective in the treatment of chronic neuropathic pain syndromes, prevention of secondary hyperalgesia in burn injuries, treatment of muscle pain in patients with fibromyalgia, metastatic bone pain and treatment of pain caused by oral mucositis.
\end{abstract}

Palliat Med Pract 2020; 14, 3: 192-197

\section{Introduction}

Ketamine is an anaesthetic with unique properties. Synthesised for the first time in the early 1960s, it causes dissociative anaesthesia and sedation, amnesia, and analgesia [1]. Ketamine does not interfere with the functioning of the respiratory and circulatory systems, and does not suppress the pharyngeal and laryngeal reflexes, it is the drug of choice in anaesthesia in trauma and disaster patients. Due to hallucinogenic effects of ketamine, its use in anaesthesiology for general anaesthesia purposes was significantly reduced in the 1980s. For several years ketamine has been gaining popularity again, especially in the treatment of pain and depression. At present, the drug is used in the treatment of acute and chronic pain, especially pain resistant to usual management methods [2]. Ketamine contraindicated in patients allergic to the drug, in patients with eclampsia or at risk of eclampsia, in patients with myocardial diseases, after brain injury, with a history of mental disorders, and with suspected or diagnosed schizophrenia.

\section{Physicochemical and pharmacokinetic properties of ketamine}

Ketamine is a lipid-soluble $238 \mathrm{~g} / \mathrm{mol}$ molecule that quickly penetrates the blood-brain barrier. Its volume of distribution is 2.3 litre/kg, pKa 7.5, and protein binding of $20-30 \%$. Ketamine can be administered intravenously, subcutaneously, intramuscularly and transmucosally. Ketamine is a racemic mixture: the S-enantiomer shows four times stronger analgesic effect, compared to the R-enantiomer [3]. In intravenous administration, the bioavailability of ketamine is $100 \%$; in intranasal administration, it is $25-50 \%$. In case of oral administration, ketamine undergoes the first-pass effect and the bioavailability is $17-29 \%$ [4]. In case of local administration, the bioavailability of ketamine is approx. 5\% [5].

The half-life of ketamine in the elimination phase is 3-5 hours; however, analgesic effects may occur up to 12 weeks [6]. The drug is metabolised by the liver, the primary enzyme responsible for $\mathrm{N}$-demeth-

\footnotetext{
Address for correspondence:

Anna Rupniewska-Ładyko

Centre of Postgraduate Medical Education

Marymoncka 99/103, 01-813 Warsaw

e-mail: aavr@interia.pl 
ylation of ketamine to norketamine (an active metabolite, 33\% stronger than the parent compound) is CYP3A4, with CYP2B6 and CYP2C9 taking a less significant part in that process. Norketamine represents $80 \%$ of the metabolites, the remaining $20 \%$ are 4-OH-ketamine and 5-OH-ketamine (inactive metabolites). Ketamine is excreted in urine $(91 \%)$, and faeces (3\%).

\section{Mechanisms of analgesic action of ketamine}

The mechanism of the analgesic effect of ketamine has not been fully explained. This effect is observed mainly in N-methyl-d-aspartate receptors (NMDA receptors), which reduces the level of glutamate, which is the main stimulating neurotransmitter in the central nervous system (CNS).

The NMDA receptor is an ionotropic glutamate receptor that plays a key role in neuroplasticity - a process that allows, depending on activity, to facilitate (long-term reinforcement) or inhibit (long-term suppression) synaptic transmission. The NMDA receptor transmits sodium, potassium and calcium cations. The incorporation of an endogenous ligand such as glutamate is not sufficient to activate it; a condition for activation of the NMDA receptor is the simultaneous incorporation of glycine or serine molecules and a change in the membrane potential of the cell (depolarisation). At rest, the NMDA receptor is additionally blocked by magnesium, which prevents ion flow. There are different subtypes of NMDA receptors: GluN1, GluN2A, GluN2B, GluN2C and GluN2D or NR1, and NR2A-D.

The activation of the NMDA receptor sensitises to pain, while ketamine weakens this phenomenon. Decreased glutamate levels reduce the sensitivity of the cerebral cortex and limbic system to painful stimuli [7].The definitive antinociceptive effect is caused by blocking the NMDA receptor GluN2B subunit in the spinal cord [8]. Ketamine is also a muscarinic receptor antagonist in the CNS, interacting with opioid and adrenergic $\alpha$ - and $\beta$-receptors. Ketamine also binds to $\sigma$-receptors, which are considered as target proteins for a potentially new class of antidepressants. Moreover, ketamine modifies the inflammatory and immune response, which leads to lower levels of proinflammatory mediators [9, 10]. Ketamine also strengthens endogenous antinociceptive systems - probably due to the activation of serotonergic and norepinergic pathways and inhibition of their reuptake [11]. Moreover, ketamine inhibits the nitric oxide synthase which enhances its analgesic effects [12].

\section{Review of ketamine clinical trials}

\section{Intravenous route}

The analgesic effect of ketamine in case of intravenous administration occurs after approx. 30 seconds and lasts 5-30 minutes $[7,13]$. Ketamine has an analgesic effect in chronic neuropathic pain syndromes. A single administration of a subanaesthetic dose $(0.5 \mathrm{mg} / \mathrm{kg}$ or less) may, after 5-10 minutes for a short period of time (2-3 hours), reduce pain, and symptoms of allodynia and hyperaesthesia [14]. Perioperative administration of ketamine may decrease opioid consumption in the post-operative period, as observed after abdominal, chest and orthopaedic surgeries. The analgesic effect observed in connection with subanaesthetic doses was independent of the type of intraoperative opioid used [15]. Ketamine used during orthopaedic surgeries reduces pain during post-operative and convalescence periods [16].

The trial carried out on a model of diabetic neuropathy in animals showed that intravenous infusion of ketamine in a subanaesthetic dose for 5 days may reduce hyperalgesia and increase the response to opioids in the long term [17]. In an experimental model of human burn injuries, it was found that ketamine reduces the area of secondary hyperalgesia [18]. Moreover, the beneficial effects of a two-day intravenous infusion of ketamine at the dose of $100 \mathrm{mg} /$ day for the treatment of bone pain caused by metastases were described [19]. The effectiveness of ketamine has been also confirmed in patients with fibromyalgia, whose muscle pain was reduced [20].

Among patients with phantom limb pain, more than $90 \%$ reduction in pain intensity was observed 30 minutes after administering intravenous ketamine infusion at a dose of $0.4 \mathrm{mg} / \mathrm{kg}$ over one hour, as compared to placebo [21]. Ketamine administered intravenously (bolus of $0.1 \mathrm{mg} / \mathrm{kg}$, followed by an infusion of $0.42 \mathrm{mg} / \mathrm{kg} / \mathrm{h}$ ) reduced pain by 2 points on the NRS (numerical rating scale) 48 hours after the infusion, as compared to placebo [22]. In patients with post-herpetic neuralgia, ketamine administered intravenously at a dose of $0.15 \mathrm{mg} / \mathrm{kg}$ over a period of 10 minutes resulted in a 50\% reduction in pain intensity $15-45 \mathrm{~min}$ utes after the infusion, as compared to placebo [23].

The intravenous infusion of ketamine at the dose of $0.6 \mathrm{mg} / \mathrm{kg}$ for 4 hours was used to treat ischaemic limb pain - the pain relief lasted for 5 days [24]. Ketamine administered intravenously in repeated infusions in complex regional pain syndrome (CRPS) provided analgesia for 2 months after treatment completion $[25,26]$. In 10 patients with CRPS type 1 (CRPS-1), the infusion of ketamine administered intravenously 
(scheme for $70 \mathrm{~kg}$ : 0-5 minutes: $1.5 \mathrm{mg}, 20-25 \mathrm{~min}-$ utes: $3,0 \mathrm{mg}, 40-45$ minutes: $4.5 \mathrm{mg}, 60-65$ minutes: $6.0 \mathrm{mg}, 80-85$ minutes: $7,5 \mathrm{mg}, 100-105$ minutes: 9,0 mg, and 120-125 minutes: $10.5 \mathrm{mg}$ ) caused a decrease in pain, and this effect lasted for 10 weeks [27].

There are reports of beneficial analgesic effect of ketamine in patients with severe headache. Ketamine was administered in an intravenous infusion at a dose of $0.1-1 \mathrm{mg} / \mathrm{kg} / \mathrm{h}$ in 77 patients in order to stop a headache episode - the treatment reduced the current symptoms but did not bring long-term pain relief [28].

The analgesic efficacy of ketamine was tested in combination with other drugs. Magnesium sulphate, which binds to the NMDA receptor channels, can be administered simultaneously with ketamine to increase the analgesic effect. Intravenous administration of a ketamine dose of $0.5 \mathrm{mg} / \mathrm{kg}$ applied for 2 hours and a dose of magnesium sulphate of $3000 \mathrm{mg}$ administered for 30 minutes to 2 patients with chronic cluster headache provided immediate pain relief, reduced suicidal thoughts, and frequency and intensity of pain for up to 6 weeks [29].

\section{Intranasal route}

The intranasal route of ketamine administration has several advantages. A large surface area, high permeability and extensive vascularisation of the nasal mucosa cause rapid absorption of the drug [30]. In a cross-over trial, ketamine was administered intranasally to 20 patients with breakthrough pain, randomly assigned to groups receiving $10-50 \mathrm{mg}$ of ketamine (patient-controlled dose) or placebo - in $45 \%$ of patients treated with ketamine, pain intensity was reduced by $40 \%$ or more, compared to $5 \%$ in the placebo group $(p=0.0078)$ [31].

Intranasal ketamine and fentanyl and their effect on post-traumatic pain in children aged 8-17 years were comared in the PRIME trial. The primary endpoint was the reduction of pain intensity according to the NRS, 30 minutes after the intervention. Ketamine was comparable to fentanyl in terms of analgesic efficacy; however, the risk of adverse events was slightly higher in patients treated with ketamine [32].

Migraine patients may benefit from treatment with ketamine administered through nasal mucosa. Randomised controlled trials on the effect of ketamine on migraine with aura have shown that a dose of $25 \mathrm{mg}$ of ketamine administered intranasally reduces the severity and sometimes also the duration of aura $[33,34]$. The S-ketamine is registered and administered intranasally in the treatment of patients with depression resistant to other antidepressants in the United States.

\section{Inhalation route}

Ketamine can be effective in treating respiratory diseases. The bioavailability of nebulised ketamine is 20-40\% [35]. In a model of bronchial asthma in animals, it has been observed that ketamine sprayed directly into the airway inhibits bronchial hyperreactivity, reduces inflammation and causes a decrease in the number of pro-inflammatory mediators in bronchial secretion [36].

Ketamine has beneficial effects on respiration by increasing the level of endogenous catecholamines, which bind to beta receptors in the lungs and cause bronchial dilatation and reduced airway resistance [37, 38]. Inhalational ketamine can also be used to manage pain. The cases of five patients with severe pain who were treated with ketamine in line with three dosing regimens $(0.75 \mathrm{mg} / \mathrm{kg}, 1 \mathrm{mg} / \mathrm{kg}$ and $1.5 \mathrm{mg} / \mathrm{kg})$ using a breath-actuated nebuliser, have been described. All patients had analgesic effect, no contraindications to ketamine were found. One patient experienced moderate dizziness which subsided spontaneously after 60 minutes, while another patient experienced a change of mood, described as "relaxed and happy". None of the patients showed elevated heart rate or arterial blood pressure [39].

\section{Local administration}

The mechanisms associated with peripheral analgesic action of ketamine are related to the influence on the metabolic pathway of nitric oxide and the binding to NMDA receptors on epidermal keratinocytes [40, 41], which, as a result of trauma or inflammation, participate in pain formation through interactions with nerve endings $[42,43]$. The use of ketamine externally at the site of pain, has many advantages - the minimal systemic absorption limits the incidence of adverse effects [44]. Additionally, local analgesics have direct access to the pain site; they are also convenient and administered pain-free [45].

The NMDA receptors take part in nociception and are located in unmyelinated and myelinated axons in peripheral somatic tissues, which are a potential site of analgesic ketamine action $[46,47]$. Additionally, ketamine affects opioid receptors [48], muscarinic receptors [49, 50], ionic channels $(\mathrm{Na}, \mathrm{K})$ [51], neurotransmitters (dopamine and serotonin), and neuronal nitric oxide synthase [40, 52]. Ketamine has an anti-inflammatory effect through the Toll-like receptor associated with interleukin-1 [53].

The concentration of ketamine applied locally is $0.5-10 \%$, but usually it is $0.5-2.0 \%$. Ketamine is combined with various carriers, mainly Lipoderm, white petroleum jelly or isopropyl palmitate [54]. The optimal dose and frequency of use have not yet been clearly established. 
Several patients with pain treated with locally applied ketamine were described in literature. In five patients with neuropathic pain $10 \%$ ketamine was applied three times per day for two weeks, and pain intensity was reduced by $14-63 \%$ after two weeks [55]. In a patient with oral cancer and radiation-induced oral mucositis, ketamine in the form of $20 \mathrm{mg} / 5 \mathrm{ml}$ solution was used, and a one-minute rinsing provided quick relief of symptoms, and after a week of daily application, the analgesic effect was observed for several hours [56].

\section{Side effects}

Given the potential risk of repeated intravenous administration, ketamine has limited use in the treatment of chronic pain syndromes. Acute dose-dependent side effects such as hallucinations, nightmares, delirium, dizziness, vision impairment, nystagmus, hearing impairment, hypertension, tachycardia, excessive salivation, nausea and vomiting and laryngeal spasm limit the use of the drug. Ketamine is characterised by a narrow therapeutic window between analgesia and excessive sedation or psychomimetic actions. Long-term use of ketamine is associated with short- and long-term memory loss, ketamine-induced vesicopathy, a temporary increase in liver enzyme concentration, and psychophysical dependence $[2$, 57].

Ketamine causes a dose-dependent release of endogenous catecholamines through the sympathetic nervous system [58]. Higher doses of ketamine temporarily cause tachycardia and hypertension, which is a problem in patients with cardiovascular diseases [59]. Ketamine also has negative inotropic properties and should be avoided in patients with cardiovascular diseases such as heart failure and in patients at risk of myocardial infarction [60].

On the other hand, unlike opioids, which can cause respiratory depression, ketamine has a beneficial effect on respiration by increasing the concentration of endogenous catecholamines. Unlike non-steroidal anti-inflammatory drugs, ketamine does not cause gastrointestinal bleeding. Although ketamine affects the opioid receptors, it does not slow down intestinal peristalsis [60]. These properties make ketamine to be considered as an alternative analgesic, especially in seriously ill patients with an increased risk of respiratory depression and gastrointestinal bleeding [61]. Moreover, since severe pain may be associated with suicidal thoughts and attempts, antidepressant properties make ketamine a useful option to treat patients who entertain suicidal thoughts [62].

\section{Summary}

The use of ketamine as an adjuvant drug may be an effective method of pain management for many patients. Although the results of majority of the studies conducted so far are optimistic, they usually concern small groups of patients in randomised, observational and retrospective studies. The recommendations for the use of ketamine may therefore change with the emergence of new studies that present compelling scientific evidence. Although the use of ketamine has promising effects, the drug should be used with great caution and as individually recommended by a health professional.

\section{Declaration of conflict of interests}

The author declare that there is no conflict of interest.

\section{Funding}

None declared.

\section{References}

1. Domino EF, Chodoff P, Corssen G. Pharmacologic effects of Ci-581, a new dissociative anesthetic, in man. Clin Pharmacol Ther. 1965; 6: 279-291, doi: 10.1002/cpt196563279, indexed in Pubmed: 14296024.

2. Pribish A, Wood N, Kalava A. A Review of Nonanesthetic Uses of Ketamine. Anesthesiol Res Pract. 2020; 2020: 5798285, doi: 10.1155/2020/5798285, indexed in Pubmed: 32308676.

3. Quibell R, Prommer EE, Mihalyo $M$, et al. Ketamine*. J Pain Symptom Manage. 2011; 41(3): 640-649, doi: 10.1016/j.jpainsymman.2011.01.001, indexed in Pubmed: 21419322.

4. Aroni F, lacovidou N, Dontas I, et al. Pharmacological aspects and potential new clinical applications of ketamine: reevaluation of an old drug. J Clin Pharmacol. 2009; 49(8): 957-964, doi: 10.1177/0091270009337941, indexed in Pubmed: 19546251.

5. Li L, Vlisides PE. Ketamine: 50 Years of Modulating the Mind. Front Hum Neurosci. 2016; 10: 612, doi: 10.3389/fnhum.2016.00612, indexed in Pubmed: 27965560.

6. Michelet D, Brasher $C$, Horlin AL, et al. Ketamine for chronic non-cancer pain: A meta-analysis and trial sequential analysis of randomized controlled trials. Eur J Pain. 2018; 22(4): 632-646, doi: 10.1002/ejp.1153, indexed in Pubmed: 29178663.

7. Walters MK, Farhat J, Bischoff J, et al. Ketamine as an Analgesic Adjuvant in Adult Trauma Intensive Care Unit Patients With Rib Fracture. Ann Pharmacother. 2018; 52(9): 849-854, doi: 10.1177/1060028018768451, indexed in Pubmed: 29607659.

8. Sleigh J, Harvey M, Voss L, et al. Ketamine - More mechanisms of action than just NMDA blockade. Trends in Anaesthesia and Critical Care. 2014; 4(2-3): 76-81, doi: 10.1016/j.tacc.2014.03.002.

9. Liu FL, Chen TL, Chen RM. Mechanisms of ketamine-induced immunosuppression. Acta Anaesthesiol Taiwan. 2012; 50(4): 172-177, doi: 10.1016/j.aat.2012.12.001, indexed in Pubmed: 23385040. 
10. De Kock M, Loix S, Lavand'homme P. Ketamine and peripheral inflammation. CNS Neurosci Ther. 2013; 19(6): 403-410, doi: 10.1111/cns.12104, indexed in Pubmed: 23574634.

11. Koizuka S, Obata H, Sasaki M, et al. Systemic ketamine inhibits hypersensitivity after surgery via descending inhibitory pathways in rats. Can J Anaesth. 2005; 52(5): 498-505, doi: 10.1007/BF03016530, indexed in Pubmed: 15872129.

12. Gordh T, Karlsten R, Kristensen J. Intervention with spinal NMDA, adenosine, and NO systems for pain modulation. Ann Med. 1995; 27(2): 229-234, doi: 10.3109/07853899509031964, indexed in Pubmed: 7632419.

13. Davis WD, Davis KA, Hooper K. The Use of Ketamine for the Management of Acute Pain in the Emergency Department. Adv Emerg Nurs J. 2019; 41(2): 111-121, doi: 10.1097/TME.0000000000000238, indexed in Pubmed: 31033658.

14. Backonja M, Arndt G, Gombar KA, et al. Response of chronic neuropathic pain syndromes to ketamine: a preliminary study. Pain. 1994; 56(1): 51-57, doi: 10.1016/03043959(94)90149-x, indexed in Pubmed: 8159441.

15. Laskowski K, Stirling A, McKay WP, et al. A systematic review of intravenous ketamine for postoperative analgesia. Can J Anaesth. 2011; 58(10): 911-923, doi: 10.1007/s12630011-9560-0, indexed in Pubmed: 21773855.

16. Remérand F, Le Tendre $C$, Baud $A$, et al. The early and delayed analgesic effects of ketamine after total hip arthroplasty: a prospective, randomized, controlled, double-blind study. Anesth Analg. 2009; 109(6): 1963-1971, doi: 10.1213/ANE.0b013e3181bdc8a0, indexed in Pubmed: 19923527.

17. Mak P, Broadbear JH, Kolosov A, et al. Long-Term Antihyperalgesic and Opioid-Sparing Effects of 5-Day Ketamine and Morphine Infusion („Burst Ketamine") in Diabetic Neuropathic Rats. Pain Med. 2015; 16(9): 1781-1793, doi: 10.1111/pme.12735, indexed in Pubmed: 25800174.

18. McGuinness SK, Wasiak J, Cleland H, et al. A systematic review of ketamine as an analgesic agent in adult burn injuries. Pain Med. 2011; 12(10): 1551-1558, doi: 10.1111/j. 1526-4637.2011.01220.x, indexed in Pubmed: 21880111.

19. Mercadante $S$, Villari $P$, Ferrera $P$, et al. Opioid switching and burst ketamine to improve the opioid response in patients with movement-related pain due to bone metastases. Clin J Pain. 2009; 25(7): 648-649, doi: 10.1097/AJP.0b013e3181a68a85, indexed in Pubmed: 19692808.

20. Graven-Nielsen T, Aspegren Kendall S, Henriksson KG, et al. Ketamine reduces muscle pain, temporal summation, and referred pain in fibromyalgia patients. Pain. 2000; 85(3): 483-491, doi: 10.1016/s0304-3959(99)00308-5, indexed in Pubmed: 10781923.

21. Amr YM. Multi-day low dose ketamine infusion as adjuvant to oral gabapentin in spinal cord injury related chronic pain: a prospective, randomized, double blind trial. Pain Physician. 2010; 13(3): 245-249, indexed in Pubmed: 20495588.

22. Nikolajsen $\mathrm{L}$, Hansen $\mathrm{CL}$, Nielsen J, et al. The effect of ketamine on phantom pain: a central neuropathic disorder maintained by peripheral input. Pain. 1996; 67(1): 69-77, doi: 10.1016/0304-3959(96)03080-1, indexed in Pubmed: 8895233.

23. Eide PK, Jørum E, Stubhaug A, et al. Relief of post-herpetic neuralgia with the N-methyl-D-aspartic acid receptor antagonist ketamine: a double-blind, cross-over comparison with morphine and placebo. Pain. 1994; 58(3): 347-354, doi: 10.1016/0304-3959(94)90129-5, indexed in Pubmed: 7838584.

24. Mitchell AC, Fallon MT. A single infusion of intravenous ketamine improves pain relief in patients with critical limb ischaemia: results of a double blind randomised controlled trial. Pain. 2002; 97(3): 275-281, doi: 10.1016/s03043959(02)00033-7, indexed in Pubmed: 12044624.

25. Becerra L, Schwartzman RJ, Kiefer RT, et al. CNS Measures of Pain Responses Pre- and Post-Anesthetic Ketamine in a Patient with Complex Regional Pain Syndrome. Pain Med. 2015; 16(12): 2368-2385, doi: 10.1111/pme.12939, indexed in Pubmed: 26745152.

26. Sigtermans MJ, van Hilten JJ, Bauer MCR, et al. Ketamine produces effective and long-term pain relief in patients with Complex Regional Pain Syndrome Type 1. Pain. 2009; 145(3): 304-311, doi: 10.1016/j.pain.2009.06.023, indexed in Pubmed: 19604642.

27. Sigtermans M, Noppers I, Sarton E, et al. An observational study on the effect of $\mathrm{S}+$-ketamine on chronic pain versus experimental acute pain in Complex Regional Pain Syndrome type 1 patients. Eur J Pain. 2010; 14(3): 302-307, doi: 10.1016/j.ejpain.2009.05.012, indexed in Pubmed: 19540140.

28. Pomeroy JL, Marmura MJ, Nahas SJ, et al. Ketamine Infusions for Treatment Refractory Headache. Headache. 2017; 57(2): 276-282, doi: 10.1111/head.13013, indexed in Pubmed: 28025837.

29. Moisset $X$, Clavelou $P$, Lauxerois $M$, et al. Ketamine Infusion Combined With Magnesium as a Therapy for Intractable Chronic Cluster Headache: Report of Two Cases. Headache. 2017; 57(8): 1261-1264, doi: 10.1111/head.13135, indexed in Pubmed: 28670718.

30. Singh V, Shteamer J, Lowe J, et al. Central sensitization and its role in chronic pain: What can ketamine do? Indian Journal of Pain. 2020; 34(1): 3, doi: 10.4103/ijpn.ijpn 2520.

31. Singh V, Gillespie TW, Harvey RD. Intranasal Ketamine and Its Potential Role in Cancer-Related Pain. Pharmacotherapy. 2018; 38(3): 390-401, doi: 10.1002/phar.2090, indexed in Pubmed: 29396996.

32. Frey TM, Florin TA, Caruso M, et al. Effect of Intranasal Ketamine vs Fentanyl on Pain Reduction for Extremity Injuries in Children: The PRIME Randomized Clinical Trial. JAMA Pediatr. 2019; 173(2): 140-146, doi: 10.1001/jamapediatrics.2018.4582, indexed in Pubmed: 30592476.

33. Afridi SK, Giffin NJ, Kaube $\mathrm{H}$, et al. A randomized controlled trial of intranasal ketamine in migraine with prolonged aura. Neurology. 2013; 80(7): 642-647, doi: 10.1212/WNL.0b013e3182824e66, indexed in Pubmed: 23365053.

34. Kaube H, Herzog J, Käufer $\mathrm{T}$, et al. Aura in some patients with familial hemiplegic migraine can be stopped by intranasal ketamine. Neurology. 2000; 55(1): 139-141, doi: 10.1212/wnl.55.1.139, indexed in Pubmed: 10891926.

35. Yanagihara $\mathrm{Y}$, Ohtani M, Kariya S, et al. Plasma concentration profiles of ketamine and norketamine after administration of various ketamine preparations to healthy Japanese volunteers. Biopharm Drug Dispos. 2003; 24(1): 37-43, doi: 10.1002/bdd.336, indexed in Pubmed: 12516077.

36. Zhu MM, Zhou QH, Zhu MH, et al. Effects of nebulized ketamine on allergen-induced airway hyperresponsiveness and inflammation in actively sensitized Brown-Norway rats. J Inflamm (Lond). 2007; 4: 10, doi: 10.1186/14769255-4-10, indexed in Pubmed: 17480224.

37. Ehieli E, Yalamuri S, Brudney CS, et al. Analgesia in the surgical intensive care unit. Postgrad Med J. 2017; 93(1095): 38-45, doi: 10.1136/postgradmedj-2016-134047, indexed in Pubmed: 27777355.

38. Patanwala AE, Martin JR, Erstad BL. Ketamine for Analgosedation in the Intensive Care Unit: A Systematic Review. J Intensive Care Med. 2017; 32(6): 387-395, doi: 10.1177/0885066615620592, indexed in Pubmed: 26647407. 
39. Drapkin J, Masoudi A, Butt M, et al. Administration of Nebulized Ketamine for Managing Acute Pain in the Emergency Department: A Case Series. Clin Pract Cases Emerg Med. 2020; 4(1): 16-20, doi: 10.5811/cpcem.2019.10.44582, indexed in Pubmed: 32064416.

40. Romero TRL, Galdino GS, Silva GC, et al. Ketamine activates the L-arginine/Nitric oxide/cyclic guanosine monophosphate pathway to induce peripheral antinociception in rats. Anesth Analg. 2011; 113(5): 1254-1259, doi: 10.1213/ANE.0b013e3182285dda, indexed in Pubmed: 21788321.

41. Fischer M, Glanz D, Urbatzka M, et al. Keratinocytes: a source of the transmitter L-glutamate in the epidermis. Exp Dermatol. 2009; 18(12): 1064-1066, doi: 10.1111/j. 1600-0625.2009.00886.x, indexed in Pubmed: 19397696.

42. Zhao P, Barr TP, Hou Q, et al. Voltage-gated sodium channel expression in rat and human epidermal keratinocytes: evidence for a role in pain. Pain. 2008; 139(1): 90-105, doi: 10.1016/j.pain.2008.03.016, indexed in Pubmed: 18442883.

43. Radtke C, Vogt PM, Devor M, et al. Keratinocytes acting on injured afferents induce extreme neuronal hyperexcitability and chronic pain. Pain. 2010; 148(1): 94-102, doi: 10.1016/j.pain.2009.10.014, indexed in Pubmed: 19932564.

44. Stanos SP. Topical agents for the management of musculoskeletal pain. J Pain Symptom Manage. 2007; 33(3): 342355, doi: 10.1016/j.jpainsymman.2006.11.005, indexed in Pubmed: 17349504.

45. Archer DF, Cullins V, Creasy GW, et al. The impact of improved compliance with a weekly contraceptive transdermal system (Ortho Evra) on contraceptive efficacy. Contraception. 2004; 69(3): 189-195, doi: 10.1016/j.contraception.2003.10.006, indexed in Pubmed: 14969665.

46. Carlton SM, Hargett GL, Coggeshall RE. Localization and activation of glutamate receptors in unmyelinated axons of rat glabrous skin. Neurosci Lett. 1995; 197(1): 25-28, doi: 10.1016/0304-3940(95)11889-5, indexed in Pubmed: 8545047.

47. Coggeshall RE, Carlton SM. Ultrastructural analysis of NMDA, AMPA, and kainate receptors on unmyelinated and myelinated axons in the periphery. J Comp Neurol. 1998; 391(1): 78-86, doi: 10.1002/(sici)1096-9861(19980202)391:1<78::aid-cne7 > 3.3.co;2-8, indexed in Pubmed: 9527543.

48. Gupta A, Devi LA, Gomes I. Potentiation of $\mu$-opioid receptor-mediated signaling by ketamine. J Neurochem. 2011; 119(2): 294-302, doi: 10.1111/j.1471-4159.2011.07361.x, indexed in Pubmed: 21692801.

49. Moaddel R, Abdrakhmanova G, Kozak J, et al. Sub-anesthetic concentrations of $(\mathrm{R}, \mathrm{S})$-ketamine metabolites inhibit acetylcholine-evoked currents in $\alpha 7$ nicotinic acetylcholine receptors. European Journal of Pharmacology. 2013; 698(1-3): 228-234, doi: 10.1016/j.ejphar.2012.11.023.

50. Murrough JW. Ketamine as a novel antidepressant: from synapse to behavior. Clin Pharmacol Ther. 2012; 91(2):
303-309, doi: 10.1038/clpt.2011.244, indexed in Pubmed: 22205190.

51. Schnoebel R, Wolff M, Peters SC, et al. Ketamine impairs excitability in superficial dorsal horn neurones by blocking sodium and voltage-gated potassium currents. Br J Pharmacol. 2005; 146(6): 826-833, doi: 10.1038/sj.bjp.0706385, indexed in Pubmed: 16151436.

52. Cohen SP, Bhatia A, Buvanendran A, et al. Consensus Guidelines on the Use of Intravenous Ketamine Infusions for Chronic Pain From the American Society of Regional Anesthesia and Pain Medicine, the American Academy of Pain Medicine, and the American Society of Anesthesiologists. Reg Anesth Pain Med. 2018; 43(5): 521-546, doi: 10.1097/AAP.0000000000000808, indexed in Pubmed: 29870458.

53. Liu FL, Chen TL, Chen RM. Mechanisms of ketamine-induced immunosuppression. Acta Anaesthesiol Taiwan. 2012; 50(4): 172-177, doi: 10.1016/j.aat.2012.12.001, indexed in Pubmed: 23385040.

54. Kopsky DJ. Keppel Hesselink JM, Bhaskar A. at al. Analgesic effects of topical ketamine. Minerva Anestesiol. 2015; 81(4): 440-449.

55. Rabi J, Minori J, Abad H, et al. Topical Ketamine $10 \%$ for Neuropathic Pain in Spinal Cord Injury Patients: An Open-Label Trial. Int J Pharm Compd. 2016; 20(6): 517520, indexed in Pubmed: 28339391.

56. Slatkin NE, Rhiner M. Topical ketamine in the treatment of mucositis pain. Pain Med. 2003; 4(3): 298-303, doi: 10.1046/j. 1526-4637.2003.03032.x, indexed in Pubmed: 12974832.

57. Middela S, Pearce I. Ketamine-induced vesicopathy: a literature review. Int J Clin Pract. 2011; 65(1): 27-30, doi: 10.1111/j.1742-1241.2010.02502.x, indexed in Pubmed: 21155941.

58. Tobias JD, Leder M. Procedural sedation: A review of sedative agents, monitoring, and management of complications. Saudi J Anaesth. 2011; 5(4): 395-410, doi: 10.4103/1658-354X.87270, indexed in Pubmed: 22144928.

59. Wampole CR, Smith KE. Beyond Opioids for Pain Management in Adult Critically III Patients. J Pharm Pract. 2019; 32(3): 256-270, doi: 10.1177/0897190019834479, indexed in Pubmed: 30845871.

60. Erstad BL, Patanwala AE. Ketamine for analgosedation in critically ill patients. J Crit Care. 2016; 35: 145-149, doi: 10.1016/j.jcrc.2016.05.016, indexed in Pubmed: 27481750.

61. Schwenk ES, Viscusi ER, Buvanendran A, et al. Consensus Guidelines on the Use of Intravenous Ketamine Infusions for Acute Pain Management From the American Society of Regional Anesthesia and Pain Medicine, the American Academy of Pain Medicine, and the American Society of Anesthesiologists. Reg Anesth Pain Med. 2018; 43(5): 456-466, doi: 10.1097/AAP.0000000000000806, indexed in Pubmed: 29870457.

62. Mallick F, McCullumsmith CB. Ketamine for Treatment of Suicidal Ideation and Reduction of Risk for Suicidal Behavior. Curr Psychiatry Rep. 2016; 18(6): 61, doi: 10.1007/s11920016-0680-7, indexed in Pubmed: 27194043. 


\section{Ketamina - unikalny lek adjuwantowy w leczeniu bólu}

Artykuł jest tłumaczeniem pracy: Rupniewska-Ładyko A., Ketamine - a unique adjuvant drug in pain treatment. Palliat. Med. Pract. 2020 tom 14, nr 3: 192-197.

Należy cytować wersję pierwotną.

\section{Streszczenie}

Ketamina jest środkiem znieczulającym o unikalnych właściwościach. Zsyntetyzowana po raz pierwszy na początku lat 60. XX wieku powoduje anestezję dysocjacyjną, sedację, amnezję i analgezję. Ze względu na działanie halucynogenne w latach 80 . znacznie ograniczono stosowanie leku. Obecnie ketaminę stosuje się w leczeniu bólu ostrego i przewlekłego, zwłaszcza bólu opornego na inne metody postępowania przeciwbólowego. Ketamina może być skuteczna w leczeniu przewlekłych zespołów bólu neuropatycznego, zapobieganiu wtórnej przeczulicy bólowej w oparzeniach, terapii bólu mięśni u pacjentów z fibromialgią, bólem kostnym spowodowanym przerzutami i leczeniu bólu wywołanego zapaleniem błony śluzowej jamy ustnej.

Palliat Med Pract 2020; 14, 3: 198-204

Słowa kluczowe: ketamina, ból, adjuwant, analgezja

\section{Wstęp}

Ketamina jest środkiem znieczulającym o unikalnych właściwościach. Zsyntetyzowana po raz pierwszy na początku lat 60 . XX wieku wywołuje stan dysocjacyjny anestezji z sedacją, amnezją i analgezją [1]. Ketamina nie zaburza funkcjonowania układu oddechowego i układu krążenia, a ponieważ nie znosi odruchów gardłowego i krtaniowego, jest lekiem z wyboru w znieczuleniu u chorych po wypadkach i katastrofach. Działanie halucynogenne ketaminy spowodowało, że w latach 80. XX wieku znacznie ograniczono jej stosowanie $w$ anestezjologii do znieczulenia ogólnego. Od kilkunastu lat ketamina ponownie zyskuje na popularności, zwłaszcza w leczeniu bólu i depresji. Obecnie lek stosuje się w leczeniu bólu ostrego i przewlekłego, zwłaszcza opornego na konwencjonalne metody postępowania [2]. Ketamina jest przeciwwskazana u chorych uczulonych na lek, w rzucawce lub zagrożeniu rzucawką, u pacjentów z chorobami mięśnia sercowego, po urazie mózgu, z zaburzeniami psychicznymi w wywiadzie, z podejrzeniem lub rozpoznaniem schizofrenii.

\section{Właściwości fizykochemiczne i farmakokinetyczne ketaminy}

Ketamina jest cząsteczką o masie $238 \mathrm{~g} / \mathrm{mol}$, rozpuszczalną w lipidach, która szybko przenika przez barierę krew-mózg. Objętość dystrybucji wynosi 2,3 l/kg, pKa 7,5, wiązanie z białkami 20-30\%. Ketaminę można podawać drogą dożylną, podskórną, domięśniową i przezśluzówkową. Ketamina jest mieszaniną racemiczną: enancjomer S wykazuje 4-krotnie silniejszy

\footnotetext{
Adres do korespondencji:

Anna Rupniewska-Ładyko

Centrum Medyczne Kształcenia Podyplomowego

ul. Marymoncka 99/103, 01-813 Warszawa

e-mail: aavr@interia.pl 
efekt przeciwbólowy, w porównaniu z enancjomerem R [3]. Po podaniu drogą dożylną biodostępność ketaminy wynosi $100 \%$, po podaniu drogą donosową $25-50 \%$. Po podaniu drogą doustną ketamina ulega efektowi pierwszego przejścia, a biodostępność wynosi 17-29\% [4]. Po podaniu miejscowym biodostępność ketaminy wynosi około $5 \%$ [5].

Okres półtrwania ketaminy w fazie eliminacji wynosi 3-5 godzin, ale działanie przeciwbólowe może występować do 12 tygodni [6]. Lek jest metabolizowany przez wątrobę, podstawowym enzymem odpowiedzialnym za N-demetylację ketaminy do norketaminy (aktywny metabolit, 33\% silniejszy od związku macierzystego) jest CYP3A4, przy mniejszym udziale CYP2B6 i CYP2C9. Norketamina stanowi 80\% metabolitów, pozostałe $20 \%$ to $4-\mathrm{OH}$-ketamina i $5-\mathrm{OH}$-ketamina (nieaktywne metabolity). Ketamina wydalana jest w $91 \%$ z moczem, w 3\% z kałem.

\section{Mechanizmy działania przeciwbólowego ketaminy}

Mechanizm działania przeciwbólowego ketaminy nie został w pełni wyjaśniony, głównie jest to działanie antagonistyczne na receptory $\mathrm{N}$-metyl-d-asparaginianowe (NMDA), co powoduje zmniejszenie poziomu glutaminianu, który jest głównym neuroprzekaźnikiem pobudzającym w ośrodkowym układzie nerwowym (OUN).

$\mathrm{N}$-metyl-d-asparaginiana jest glutaminergicznym receptorem jonotropowym, który odgrywa kluczową rolę w neuroplastyczności - procesie, który umożliwia, zależnie od aktywności, ułatwienie (długotrwałe wzmocnienie) lub hamowanie (długotrwała supresja) transmisji synaptycznej. Receptor NMDA przewodzi kationy sodu, potasu i wapnia. Przyłączenie endogennego ligandu, jakim jest glutaminian, nie jest wystarczające do jego aktywacji; warunkiem aktywacji receptora NMDA jest jednoczesne przyłączenie cząsteczek glicyny lub seryny i zmiana potencjału błonowego komórki (depolaryzacja). W stanie spoczynku receptor NMDA jest blokowany dodatkowo przez magnez, który uniemożliwia przepływ jonów. Istnieją różne podtypy receptorów NMDA: GluN1, GluN2A, GluN2B, GluN2C i GluN2D lub NR1, NR2A-D.

Aktywacja receptora NMDA uwrażliwia na ból, stąd ketamina osłabia to zjawisko. Obniżenie stężenia glutaminianu powoduje zmniejszenie wrażliwości kory mózgowej i układu limbicznego na bodźce bólowe [7]. Decydujący efekt antynocyceptywny powoduje blokada podjednostki GluN2B receptora NMDA w rdzeniu kręgowym [8]. Ketamina jest również antagonistą receptorów muskarynowych w OUN, oddziałuje z receptorami opioidowymi, a także adrenergicznymi $\alpha$ i $\beta$. Ketamina wiąże się również z receptorami $\sigma$, które uważa się za docelowe białka dla potencjalnie nowej klasy leków przeciwdepresyjnych. Ponadto, ketamina modyfikuje odpowiedź zapalną i immunologiczną, co prowadzi do obniżenia stężenia mediatorów prozapalnych $[9,10]$. Ketamina wzmacnia również endogenne układy antynocyceptywne - prawdopodobnie dzięki aktywacji szlaków serotoninergicznego i noradrenergicznego oraz hamowaniu ich wychwytu zwrotnego [11]. Ponadto, ketamina hamuje syntetazę tlenku azotu, co wzmacnia jej działanie przeciwbólowe [12].

\section{Przegląd badań klinicznych ketaminy}

\section{Droga dożylna}

Efekt analgetyczny ketaminy po podaniu drogą dożylną występuje po około 30 sekundach i trwa 5-30 minut $[7,13]$. Ketamina wykazuje efekt przeciwbólowy w przewlekłych zespołach bólu neuropatycznego. Pojedyncze podanie dawki subanestetycznej $(0,5 \mathrm{mg} / \mathrm{kg}$ lub mniejszej) może po 5-10 minutach na krótki czas (2-3 godziny) zmniejszyć natężenie bólu, objawy allodynii i przeczulicy [14]. Okołooperacyjne podanie ketaminy może zmniejszyć zużycie opioidów w okresie pooperacyjnym, co zaobserwowano po operacjach jamy brzusznej, klatki piersiowej i zabiegach ortopedycznych. Efekt przeciwbólowy obserwowany przy dawkach subanaestetycznych był niezależny od rodzaju zastosowanego śródoperacyjnie opioidu [15]. Ketamina stosowana podczas operacji ortopedycznych zmniejsza natężenie bólu w okresie pooperacyjnym i podczas rekonwalescencji [16].

Badanie przeprowadzone na modelu neuropatii cukrzycowej u zwierząt wykazało, że wlew ketaminy drogą dożylną w dawce subanestetycznej przez okres 5 dni może długotrwale zmniejszyć hiperalgezję i zwiększyć odpowiedź na opioidy [17]. W eksperymentalnym modelu oparzeń u ludzi stwierdzono, że ketamina zmniejsza obszar wtórnej przeczulicy [18]. Opisano także korzystne działanie dwudniowego wlewu ketaminy drogą dożylną w dawce $100 \mathrm{mg} /$ dobę w leczeniu bólu kostnego spowodowanym przerzutami [19]. Skuteczność ketaminy potwierdzono również u chorych z fibromialgią, u których uzyskano zmniejszenie natężenia bólu mięśni [20].

Wśród pacjentów z fantomowym bólem kończyn zaobserwowano ponad 90-procentowe zmniejszenie natężenia bólu 30 minut po wlewie drogą dożylną ketaminy w dawce $0,4 \mathrm{mg} / \mathrm{kg}$ w okresie 1 godziny w porównaniu z placebo [21]. Ketamina podana drogą dożylną (bolus $0,1 \mathrm{mg} / \mathrm{kg}$, następnie wlew $0,42 \mathrm{mg} / \mathrm{kg} / \mathrm{godz}$.) powodowała zmniejszenie natężenia bólu o 2 stopnie w NRS (skala numeryczna 
oceny natężenia bólu [numerical rating scale]), po 48 godzinach od zakończenia wlewu w porównaniu z placebo [22]. U pacjentów z neuralgią popółpaścową ketamina podawana drogą dożylną $w$ dawce $0,15 \mathrm{mg} / \mathrm{kg}$ w okresie 10 minut powodowała 50-procentowe zmniejszenie natężenia bólu 15-45 minut po zakończeniu wlewu w porównaniu z placebo [23].

Ketaminę drogą dożylną we wlewie $w$ dawce 0,6 mg/kg przez 4 godziny stosowano w leczeniu bólu niedokrwiennego kończyn - ulga w bólu utrzymywała się przez okres 5 dni [24]. Ketamina podana drogą dożylną w powtarzanych wlewach w zespole wieloobjawowego bólu miejscowego (CRPS, complex regional pain syndrome) zapewniła analgezję przez okres 2 miesięcy po zakończeniu leczenia $[25,26]$. U 10 chorych z CRPS typu 1 (CRPS-1) wlew ketaminy drogą dożylną (schemat na $70 \mathrm{~kg}$ : minuty $0-5: 1,5 \mathrm{mg}, \min 20-25: 3,0 \mathrm{mg}$, min 40-45: 4,5 mg, $\min$ 60-65: 6,0 mg, $\min 80-85: 7,5 \mathrm{mg}$, min 100-105: 9,0 mg i $\min 120-125: 10,5 \mathrm{mg}$ ) spowodował zmniejszenie natężenia bólu, efekt utrzymywał się przez okres 10 tygodni [27].

Istnieją doniesienia o korzystnym efekcie przeciwbólowym ketaminy u pacjentów z bólem głowy o silnym natężeniu. Ketaminę podano we wlewie drogą dożylną w dawce 0,1-1 mg/kg/godzinę u 77 pacjentów, w celu przerwania napadu bólu głowy - leczenie zmniejszyło bieżące dolegliwości, ale nie przyniosło długotrwałej ulgi w bólu [28].

Skuteczność analgetyczną ketaminy badano w połączeniu z innymi lekami. Siarczan magnezu, który wiąże się $z$ kanałami receptorów NMDA, może być podawany jednocześnie $z$ ketaminą $w$ celu zwiększenia efektu analgetycznego. Po podaniu drogą dożylną 2 pacjentom z przewlekłym klasterowym bólem głowy, ketamina w dawce $0,5 \mathrm{mg} / \mathrm{kg}$ stosowana przez okres 2 godzin i siarczan magnezu w dawce 3000 mg podany przez 30 minut zapewniły natychmiastową ulgę w bólu, zmniejszenie myśli samobójczych, częstości i natężenia bólu przez okres do 6 tygodni [29].

\section{Droga donosowa}

Donosową drogę podania ketaminy cechuje kilka zalet. Znaczna powierzchnia, wysoka przepuszczalność i rozległe unaczynienie błony śluzowej nosa powodują szybkie wchłanianie leku [30]. W badaniu krzyżowym ketaminę podawano drogą donosową 20 chorym z bólem przebijającym, losowo przydzielonych do grup otrzymujących 10-50 mg ketaminy (dawka kontrolowana przez pacjenta) lub placebo - u $45 \%$ chorych leczonych ketaminą uzyskano zmniejszenie natężenia bólu o $40 \%$ lub więcej, w porównaniu z $5 \%$ w grupie otrzymującej placebo $(p=0,0078)$ [31].

W badaniu PRIME porównano ketaminę i fentanyl podawane drogą donosową i ich wpływ na ból poura- zowy u dzieci w wieku 8-17 lat. Pierwszorzędowym punktem końcowym było zmniejszenie natężenia bólu według NRS 30 minut po interwencji. Ketamina była porównywalna $z$ fentanylem pod względem skuteczności analgetycznej, jednak ryzyko wystąpienia zdarzeń niepożądanych było nieco wyższe u chorych leczonych ketaminą [32].

Korzyści z leczenia ketaminą podaną przez śluzówkę nosa mogą odnieść pacjenci z migreną. Randomizowane, kontrolowane badania wpływu ketaminy na migrenę z aurą wykazały, że dawka 25 mg ketaminy podana drogą donosową zmniejsza nasilenie, a niekiedy również czas trwania aury [33, 34]. S-ketamina jest zarejestrowana i stosowana drogą donosową $w$ leczeniu chorych $z$ depresją oporną na inne leki przeciwdepresyjne w Stanach Zjednoczonych.

\section{Droga wziewna}

Ketamina może być skuteczna w leczeniu schorzeń układu oddechowego. Biodostępność nebulizowanej ketaminy wynosi $20-40 \%$ [35]. W modelu astmy oskrzelowej u zwierząt zaobserwowano, że ketamina rozpylona bezpośrednio do dróg oddechowych powoduje zahamowanie nadreaktywności oskrzeli, zmniejsza zapalenie i powoduje spadek ilości mediatorów stanu zapalnego w wydzielinie oskrzelowej [36].

Ketamina korzystnie wpływa na oddychanie poprzez zwiększenie stężenia endogennych katecholamin, które wiążą się z receptorami $\beta$ w płucach i powodują rozszerzenie oskrzeli i zmniejszenie oporu w drogach oddechowych $[37,38]$. Ketaminę w postaci wziewnej można również stosować w leczeniu bólu. Opisano 5 pacjentów z bólem o silnym natężeniu, u których zastosowano ketaminę w 3 schematach dawkowania $(0,75 \mathrm{mg} / \mathrm{kg}, 1 \mathrm{mg} / \mathrm{kg}$ i $1,5 \mathrm{mg} / \mathrm{kg})$ przy użyciu nebulizatora uruchamianego oddechem. U wszystkich chorych stwierdzono efekt przeciwbólowy, u żadnego pacjenta nie stwierdzono przeciwwskazań do podania ketaminy. U 1 pacjenta wystąpiły zawroty głowy o umiarkowanym natężeniu, które ustąpiły samoistnie po 60 minutach, 1 chory doświadczył zmiany nastroju, opisywanej jako „zrelaksowany i szczęśliwy". U żadnego chorego nie stwierdzono wzrostu tętna ani ciśnienia tętniczego krwi [39].

\section{Podanie miejscowe}

Mechanizmy związane z obwodowym, przeciwbólowym działaniem ketaminy mają związek z wpływem na szlak metaboliczny tlenku azotu i wiązaniem z receptorami NMDA na keratynocytach naskórka [40, 41], które pod wpływem urazu lub stanu zapalnego biorą udział w powstawaniu bólu poprzez interakcje z zakończeniami nerwowymi [42, 43]. Stosowanie ketaminy zewnętrznie, w miejscu bólu posiada wiele 
zalet - minimalne wchłanianie ogólnoustrojowe ogranicza wystąpienie działań niepożądanych [44]. Dodatkowo, miejscowe leki przeciwbólowe cechuje bezpośredni dostęp do miejsca bólu, są wygodne, a stosowanie bezbolesne [45].

Receptory NMDA biorą udział w nocycepcji i znajdują się w niezmielinizowanych i mielinowych aksonach w obwodowych tkankach somatycznych, co stanowi potencjalne miejsce działania przeciwbólowego ketaminy $[46,47]$. Dodatkowo, ketamina wpływa na receptory opioidowe [48], receptory muskarynowe $[49,50]$, kanały jonowe ( $\mathrm{Na}, \mathrm{K})[51]$, neuroprzekaźniki (dopaminę i serotoninę) i syntetazę neuronalnego tlenku azotu [40, 52]. Ketamina wykazuje działanie przeciwzapalne poprzez receptor Toll-podobny, powiązany $z$ interleukiną 1 [53].

Stężenie ketaminy stosowanej miejscowo wynosi $0,5-10 \%$, najczęściej 0,5-2,0\%. Ketaminę łączy się $\mathrm{z}$ różnymi nośnikami, głównie lipodermem, wazeliną białą, palmitynianem izopropylowym [54]. Optymalna dawka i częstość stosowania nie zostały do tej pory jednoznacznie ustalone.

Opisano kilku chorych z bólem leczonych ketaminą podawaną miejscowo. U 5 pacjentów z bólem neuropatycznym zastosowano 10-procentową ketaminę 3 razy dziennie przez 2 tygodnie, wykazano zmniejszenie natężenia bólu o $14-63 \%$ po 2 tygodniach [55]. U pacjenta z rakiem jamy ustnej i popromiennym zapaleniem błony śluzowej zastosowano ketaminę $w$ postaci roztworu o stężeniu $20 \mathrm{mg} / 5 \mathrm{ml}$, płukanie przez 1 minutę, co zapewniło szybką ulgę w dolegliwościach, a po tygodniu codziennego stosowania obserwowano kilkugodzinny efekt przeciwbólowy [56].

\section{Działania niepożądane}

Biorąc pod uwagę potencjalne ryzyko związane z powtarzanym podaniem drogą dożylną, ketamina posiada ograniczone zastosowanie $w$ leczeniu przewlekłych zespołów bólowych. Ostre, zależne od dawki działania niepożądane, takie jak: omamy, koszmary senne, majaczenie, zawroty głowy, zaburzenia widzenia, oczopląs, zaburzenia słuchu, nadciśnienie, tachykardia, nadmierne ślinienie, nudności i wymioty oraz skurcz krtani, ograniczają stosowanie leku. Ketaminę cechuje wąskie okno terapeutyczne pomiędzy analgezją a nadmierną sedacją lub działaniami psychomimetycznymi. Długotrwałe stosowanie ketaminy wiąże się z utratą pamięci krótkoterminowej i długoterminowej, niekorzystnymi zmianami w pęcherzu moczowym (ketamine-induced vesicopathy), przejściowym wzrostem stężenia enzymów wątrobowych i uzależnieniem psychofizycznym $[2,57]$.
Ketamina powoduje zależne od dawki uwalnianie endogennych katecholamin za pośrednictwem układu nerwowego współczulnego [58]. Większe dawki ketaminy powodują przejściowo tachykardię i nadciśnienie tętnicze, co stanowi problem u pacjentów z chorobą sercowo-naczyniową [59]. Ketamina wykazuje również negatywne właściwości inotropowe i należy jej unikać u pacjentów ze schorzeniami sercowo-naczyniowymi, takimi jak niewydolność serca, i u chorych z ryzykiem wystąpienia zawału serca [60].

Z drugiej strony, w przeciwieństwie do opioidów, które mogą powodować depresję oddechową, ketamina korzystnie wpływa na oddychanie poprzez zwiększenie stężenia endogennych katecholamin. W przeciwieństwie do niesteroidowych leków przeciwzapalnych, ketamina nie powoduje krwawienia z przewodu pokarmowego. Chociaż ketamina wpływa na receptory opioidowe mu, nie powoduje zwolnienia perystaltyki jelit [60]. Właściwości te sprawiają, że niekiedy ketamina może być alternatywnym lekiem przeciwbólowym, zwłaszcza u poważnie chorych pacjentów, ze zwiększonym ryzykiem wystąpienia depresji oddechowej i krwawienia z przewodu pokarmowego [61]. Ponadto, ponieważ silny ból może być związany z myślami i próbami samobójczymi, właściwości przeciwdepresyjne powodują, że ketamina jest przydatną opcją leczenia chorych, u których pojawiają się myśli samobójcze [62].

\section{Podsumowanie}

Zastosowanie ketaminy jako leku adjuwantowego może być dla wielu chorych skuteczną metodą leczenia bólu. Chociaż wyniki większości przeprowadzonych do tej pory badań są pozytywne, jednak dotyczą zwykle niewielkich grup chorych w badaniach randomizowanych, badań obserwacyjnych i retrospektywnych. Zalecenia stosowania ketaminy mogą zatem ulec zmianie w miarę pojawiania się nowych badań, o większej sile dowodów naukowych. Pomimo że stosowanie ketaminy daje obiecujące efekty, lek powinien być stosowany ze znaczną ostrożnością i w indywidualnie określonych wskazaniach.

\section{Deklaracja konfliktu interesów}

Autorka oświadcza, że nie występuje konflikt interesów.

\section{Finansowanie}

Badanie nie było finansowane.

\section{References}

1. Domino EF, Chodoff P, Corssen G. Pharmacologic effects of $\mathrm{Ci}-581$, a new dissociative anesthetic, in man. Clin Pharma- 
col Ther. 1965; 6: 279-291, doi: 10.1002/cpt196563279, indexed in Pubmed: 14296024.

2. Pribish A, Wood N, Kalava A. A Review of Nonanesthetic Uses of Ketamine. Anesthesiol Res Pract. 2020; 2020: 5798285, doi: 10.1155/2020/5798285, indexed in Pubmed: 32308676.

3. Quibell $\mathrm{R}$, Prommer EE, Mihalyo $\mathrm{M}$, et al. Ketamine*. J Pain Symptom Manage. 2011; 41(3): 640-649, doi: 10.1016/j.jpainsymman.2011.01.001, indexed in Pubmed: 21419322.

4. Aroni F, lacovidou N, Dontas I, et al. Pharmacological aspects and potential new clinical applications of ketamine: reevaluation of an old drug. J Clin Pharmacol. 2009; 49(8): 957-964, doi: 10.1177/0091270009337941, indexed in Pubmed: 19546251.

5. Li L, Vlisides PE. Ketamine: 50 Years of Modulating the Mind. Front Hum Neurosci. 2016; 10: 612, doi: 10.3389/fnhum.2016.00612, indexed in Pubmed: 27965560.

6. Michelet D, Brasher C, Horlin AL, et al. Ketamine for chronic non-cancer pain: A meta-analysis and trial sequential analysis of randomized controlled trials. Eur J Pain. 2018; 22(4): 632-646, doi: 10.1002/ejp.1153, indexed in Pubmed: 29178663.

7. Walters MK, Farhat J, Bischoff J, et al. Ketamine as an Analgesic Adjuvant in Adult Trauma Intensive Care Unit Patients With Rib Fracture. Ann Pharmacother. 2018; 52(9): 849-854, doi: 10.1177/1060028018768451, indexed in Pubmed: 29607659.

8. Sleigh J, Harvey M, Voss L, et al. Ketamine - More mechanisms of action than just NMDA blockade. Trends in Anaesthesia and Critical Care. 2014; 4(2-3): 76-81, doi: 10.1016/j.tacc.2014.03.002.

9. Liu FL, Chen TL, Chen RM. Mechanisms of ketamine-induced immunosuppression. Acta Anaesthesiol Taiwan. 2012; 50(4): 172-177, doi: 10.1016/j.aat.2012.12.001, indexed in Pubmed: 23385040.

10. De Kock M, Loix S, Lavand'homme P. Ketamine and peripheral inflammation. CNS Neurosci Ther. 2013; 19(6): 403-410, doi: 10.1111/cns.12104, indexed in Pubmed: 23574634.

11. Koizuka S, Obata H, Sasaki M, et al. Systemic ketamine inhibits hypersensitivity after surgery via descending inhibitory pathways in rats. Can J Anaesth. 2005; 52(5): 498-505, doi: 10.1007/BF03016530, indexed in Pubmed: 15872129.

12. Gordh T, Karlsten R, Kristensen J. Intervention with spinal NMDA, adenosine, and NO systems for pain modulation. Ann Med. 1995; 27(2): 229-234, doi: 10.3109/07853899509031964, indexed in Pubmed: 7632419.

13. Davis WD, Davis KA, Hooper K. The Use of Ketamine for the Management of Acute Pain in the Emergency Department. Adv Emerg Nurs J. 2019; 41(2): 111-121, doi: 10.1097/TME.0000000000000238, indexed in Pubmed: 31033658.

14. Backonja M, Arndt G, Gombar KA, et al. Response of chronic neuropathic pain syndromes to ketamine: a preliminary study. Pain. 1994; 56(1): 51-57, doi: 10.1016/03043959(94)90149-x, indexed in Pubmed: 8159441.

15. Laskowski K, Stirling A, McKay WP, et al. A systematic review of intravenous ketamine for postoperative analgesia. Can J Anaesth. 2011; 58(10): 911-923, doi: 10.1007/s12630011-9560-0, indexed in Pubmed: 21773855.

16. Remérand $F$, Le Tendre $C$, Baud $A$, et al. The early and delayed analgesic effects of ketamine after total hip arthroplasty: a prospective, randomized, controlled, double-blind study. Anesth Analg. 2009; 109(6): 1963-1971, doi: 10.1213/ANE.0b013e3181bdc8a0, indexed in Pubmed: 19923527.

17. Mak P, Broadbear JH, Kolosov A, et al. Long-Term Antihyperalgesic and Opioid-Sparing Effects of 5-Day Ketamine and Morphine Infusion („Burst Ketamine”) in Diabetic Neuropathic Rats. Pain Med. 2015; 16(9): 1781-1793, doi: 10.1111/pme.12735, indexed in Pubmed: 25800174.

18. McGuinness SK, Wasiak J, Cleland H, et al. A systematic review of ketamine as an analgesic agent in adult burn injuries. Pain Med. 2011; 12(10): 1551-1558, doi: 10.1111/j. 1526-4637.2011.01220.x, indexed in Pubmed: 21880111.

19. Mercadante S, Villari P, Ferrera P, et al. Opioid switching and burst ketamine to improve the opioid response in patients with movement-related pain due to bone metastases. Clin J Pain. 2009; 25(7): 648-649, doi: 10.1097/AJP.0b013e3181a68a85, indexed in Pubmed: 19692808.

20. Graven-Nielsen T, Aspegren Kendall S, Henriksson KG, et al. Ketamine reduces muscle pain, temporal summation, and referred pain in fibromyalgia patients. Pain. 2000; 85(3): 483-491, doi: 10.1016/50304-3959(99)00308-5, indexed in Pubmed: 10781923.

21. Amr YM. Multi-day low dose ketamine infusion as adjuvant to oral gabapentin in spinal cord injury related chronic pain: a prospective, randomized, double blind trial. Pain Physician. 2010; 13(3): 245-249, indexed in Pubmed: 20495588.

22. Nikolajsen $\mathrm{L}$, Hansen $\mathrm{CL}$, Nielsen J, et al. The effect of ketamine on phantom pain: a central neuropathic disorder maintained by peripheral input. Pain. 1996; 67(1): 69-77, doi: 10.1016/0304-3959(96)03080-1, indexed in Pubmed: 8895233.

23. Eide PK, Jørum E, Stubhaug A, et al. Relief of post-herpetic neuralgia with the $\mathrm{N}$-methyl-D-aspartic acid receptor antagonist ketamine: a double-blind, cross-over comparison with morphine and placebo. Pain. 1994; 58(3): 347-354, doi: 10.1016/0304-3959(94)90129-5, indexed in Pubmed: 7838584.

24. Mitchell AC, Fallon MT. A single infusion of intravenous ketamine improves pain relief in patients with critical limb ischaemia: results of a double blind randomised controlled trial. Pain. 2002; 97(3): 275-281, doi: 10.1016/s03043959(02)00033-7, indexed in Pubmed: 12044624.

25. Becerra L, Schwartzman RJ, Kiefer RT, et al. CNS Measures of Pain Responses Pre- and Post-Anesthetic Ketamine in a Patient with Complex Regional Pain Syndrome. Pain Med. 2015; 16(12): 2368-2385, doi: 10.1111/pme.12939, indexed in Pubmed: 26745152.

26. Sigtermans MJ, van Hilten JJ, Bauer MCR, et al. Ketamine produces effective and long-term pain relief in patients with Complex Regional Pain Syndrome Type 1. Pain. 2009; 145(3): 304-311, doi: 10.1016/j.pain.2009.06.023, indexed in Pubmed: 19604642.

27. Sigtermans M, Noppers I, Sarton E, et al. An observational study on the effect of $S+-$ ketamine on chronic pain versus experimental acute pain in Complex Regional Pain Syndrome type 1 patients. Eur J Pain. 2010; 14(3): 302-307. doi: 10.1016/j.ejpain.2009.05.012, indexed in Pubmed: 19540140.

28. Pomeroy JL, Marmura MJ, Nahas SJ, et al. Ketamine Infusions for Treatment Refractory Headache. Headache. 2017; 57(2): 276-282, doi: 10.1111/head.13013, indexed in Pubmed: 28025837.

29. Moisset $X$, Clavelou $P$, Lauxerois $M$, et al. Ketamine Infusion Combined With Magnesium as a Therapy for Intractable Chronic Cluster Headache: Report of Two Cases. Heada- 
che. 2017; 57(8): 1261-1264, doi: 10.1111/head.13135, indexed in Pubmed: 28670718.

30. Singh V, Shteamer J, Lowe J, et al. Central sensitization and its role in chronic pain: What can ketamine do? Indian Journal of Pain. 2020; 34(1): 3, doi: 10.4103/ijpn.ijpn_25_20.

31. Singh V, Gillespie TW, Harvey RD. Intranasal Ketamine and Its Potential Role in Cancer-Related Pain. Pharmacotherapy. 2018; 38(3): 390-401, doi: 10.1002/phar.2090, indexed in Pubmed: 29396996.

32. Frey TM, Florin TA, Caruso M, et al. Effect of Intranasal Ketamine vs Fentanyl on Pain Reduction for Extremity Injuries in Children: The PRIME Randomized Clinical Trial. JAMA Pediatr. 2019; 173(2): 140-146, doi: 10.1001/jamapediatrics.2018.4582, indexed in Pubmed: 30592476.

33. Afridi SK, Giffin NJ, Kaube H, et al. A randomized controlled trial of intranasal ketamine in migraine with prolonged aura. Neurology. 2013; 80(7): 642-647, doi: 10.1212/WNL.0b013e3182824e66, indexed in Pubmed: 23365053.

34. Kaube $\mathrm{H}$, Herzog J, Käufer $\mathrm{T}$, et al. Aura in some patients with familial hemiplegic migraine can be stopped by intranasal ketamine. Neurology. 2000; 55(1): 139-141, doi: 10.1212/wnl.55.1.139, indexed in Pubmed: 10891926.

35. Yanagihara $\mathrm{Y}$, Ohtani M, Kariya S, et al. Plasma concentration profiles of ketamine and norketamine after administration of various ketamine preparations to healthy Japanese volunteers. Biopharm Drug Dispos. 2003; 24(1): 37-43, doi: 10.1002/bdd.336, indexed in Pubmed: 12516077.

36. Zhu MM, Zhou QH, Zhu MH, et al. Effects of nebulized ketamine on allergen-induced airway hyperresponsiveness and inflammation in actively sensitized Brown-Norway rats. J Inflamm (Lond). 2007; 4: 10, doi: 10.1186/14769255-4-10, indexed in Pubmed: 17480224.

37. Ehieli E, Yalamuri $S$, Brudney $C S$, et al. Analgesia in the surgical intensive care unit. Postgrad Med J. 2017; 93(1095): 38-45, doi: 10.1136/postgradmedj-2016-134047, indexed in Pubmed: 27777355.

38. Patanwala AE, Martin JR, Erstad BL. Ketamine for Analgosedation in the Intensive Care Unit: A Systematic Review. J Intensive Care Med. 2017; 32(6): 387-395, doi: 10.1177/0885066615620592, indexed in Pubmed: 26647407.

39. Drapkin J, Masoudi A, Butt M, et al. Administration of Nebulized Ketamine for Managing Acute Pain in the Emergency Department: A Case Series. Clin Pract Cases Emerg Med. 2020; 4(1): 16-20, doi: 10.5811/cpcem.2019.10.44582, indexed in Pubmed: 32064416.

40. Romero TRL, Galdino GS, Silva GC, et al. Ketamine activates the L-arginine/Nitric oxide/cyclic guanosine monophosphate pathway to induce peripheral antinociception in rats. Anesth Analg. 2011; 113(5): 1254-1259, doi: 10.1213/ANE.0b013e3182285dda, indexed in Pubmed: 21788321.

41. Fischer M, Glanz D, Urbatzka M, et al. Keratinocytes: a source of the transmitter L-glutamate in the epidermis. Exp Dermatol. 2009; 18(12): 1064-1066, doi: 10.1111/j. 1600-0625.2009.00886.x, indexed in Pubmed: 19397696.

42. Zhao P, Barr TP, Hou Q, et al. Voltage-gated sodium channel expression in rat and human epidermal keratinocytes: evidence for a role in pain. Pain. 2008; 139(1): 90-105, doi: 10.1016/j.pain.2008.03.016, indexed in Pubmed: 18442883.

43. Radtke C, Vogt PM, Devor M, et al. Keratinocytes acting on injured afferents induce extreme neuronal hyperexcitability and chronic pain. Pain. 2010; 148(1): 94-102, doi: 10.1016/j.pain.2009.10.014, indexed in Pubmed: 19932564.

44. Stanos SP. Topical agents for the management of musculoskeletal pain. J Pain Symptom Manage. 2007; 33(3): 342355, doi: 10.1016/j.jpainsymman.2006.11.005, indexed in Pubmed: 17349504.

45. Archer DF, Cullins V, Creasy GW, et al. The impact of improved compliance with a weekly contraceptive transdermal system (Ortho Evra) on contraceptive efficacy. Contraception. 2004; 69(3): 189-195, doi: 10.1016/j.contraception.2003.10.006, indexed in Pubmed: 14969665.

46. Carlton SM, Hargett GL, Coggeshall RE. Localization and activation of glutamate receptors in unmyelinated axons of rat glabrous skin. Neurosci Lett. 1995; 197(1): 25-28, doi: 10.1016/0304-3940(95)11889-5, indexed in Pubmed: 8545047.

47. Coggeshall RE, Carlton SM. Ultrastructural analysis of NMDA, AMPA, and kainate receptors on unmyelinated and myelinated axons in the periphery. J Comp Neurol. 1998; 391(1): 78-86, doi: 10.1002/(sici)1096-9861(19980202)391:1<78::aid-cne7>3.3.co;2-8, indexed in Pubmed: 9527543.

48. Gupta A, Devi LA, Gomes I. Potentiation of $\mu$-opioid receptor-mediated signaling by ketamine. J Neurochem. 2011; 119(2): 294-302, doi: 10.1111/j.1471-4159.2011.07361.x, indexed in Pubmed: 21692801.

49. Moaddel R, Abdrakhmanova G, Kozak J, et al. Sub-anesthetic concentrations of $(R, S)$-ketamine metabolites inhibit acetylcholine-evoked currents in $\alpha 7$ nicotinic acetylcholine receptors. European Journal of Pharmacology. 2013; 698(1-3): 228-234, doi: 10.1016/j.ejphar.2012.11.023.

50. Murrough JW. Ketamine as a novel antidepressant: from synapse to behavior. Clin Pharmacol Ther. 2012; 91(2): 303-309, doi: 10.1038/clpt.2011.244, indexed in Pubmed: 22205190.

51. Schnoebel R, Wolff M, Peters SC, et al. Ketamine impairs excitability in superficial dorsal horn neurones by blocking sodium and voltage-gated potassium currents. Br J Pharmacol. 2005; 146(6): 826-833, doi: 10.1038/sj.bjp.0706385, indexed in Pubmed: 16151436.

52. Cohen SP, Bhatia A, Buvanendran A, et al. Consensus Guidelines on the Use of Intravenous Ketamine Infusions for Chronic Pain From the American Society of Regional Anesthesia and Pain Medicine, the American Academy of Pain Medicine, and the American Society of Anesthesiologists. Reg Anesth Pain Med. 2018; 43(5): 521-546, doi: 10.1097/AAP.00000000000000808, indexed in Pubmed: 29870458.

53. Liu FL, Chen TL, Chen RM. Mechanisms of ketamine-induced immunosuppression. Acta Anaesthesiol Taiwan. 2012; 50(4): 172-177, doi: 10.1016/j.aat.2012.12.001, indexed in Pubmed: 23385040.

54. Kopsky DJ. Keppel Hesselink JM, Bhaskar A. at al. Analgesic effects of topical ketamine. Minerva Anestesiol. 2015; 81(4): 440-449.

55. Rabi J, Minori J, Abad H, et al. Topical Ketamine $10 \%$ for Neuropathic Pain in Spinal Cord Injury Patients: An Open-Label Trial. Int J Pharm Compd. 2016; 20(6): 517520, indexed in Pubmed: 28339391.

56. Slatkin NE, Rhiner M. Topical ketamine in the treatment of mucositis pain. Pain Med. 2003; 4(3): 298-303, doi: 10.1046/j. 1526-4637.2003.03032.x, indexed in Pubmed: 12974832.

57. Middela S, Pearce I. Ketamine-induced vesicopathy: a literature review. Int J Clin Pract. 2011; 65(1): 27-30, doi: 10.1111/j.1742-1241.2010.02502.x, indexed in Pubmed: 21155941. 
58. Tobias JD, Leder M. Procedural sedation: A review of sedative agents, monitoring, and management of complications. Saudi J Anaesth. 2011; 5(4): 395-410, doi: 10.4103/1658-354X.87270, indexed in Pubmed: 22144928.

59. Wampole CR, Smith KE. Beyond Opioids for Pain Management in Adult Critically III Patients. J Pharm Pract. 2019; 32(3): 256-270, doi: 10.1177/0897190019834479, indexed in Pubmed: 30845871.

60. Erstad BL, Patanwala AE. Ketamine for analgosedation in critically ill patients. J Crit Care. 2016; 35: 145-149, doi: 10.1016/j.jcrc.2016.05.016, indexed in Pubmed: 27481750.
61. Schwenk ES, Viscusi ER, Buvanendran A, et al. Consensus Guidelines on the Use of Intravenous Ketamine Infusions for Acute Pain Management From the American Society of Regional Anesthesia and Pain Medicine, the American Academy of Pain Medicine, and the American Society of Anesthesiologists. Reg Anesth Pain Med. 2018; 43(5): 456-466, doi: 10.1097/AAP.0000000000000806, indexed in Pubmed: 29870457.

62. Mallick F, McCullumsmith CB. Ketamine for Treatment of Suicidal Ideation and Reduction of Risk for Suicidal Behavior. Curr Psychiatry Rep. 2016; 18(6): 61, doi: 10.1007/s11920016-0680-7, indexed in Pubmed: 27194043. 